\title{
Electrical and Mechanical Properties of Nitrile Rubber (NR) Filled with Industrial waste and by Product from Manufacture of Ferrosilicon Alloys in Egyptian Chemical Industries Company
}

\author{
Mostafa M. Dief Allah' ${ }^{1}$ Zaid M. Ali ${ }^{2}$, Nehad N. Rozik ${ }^{3}$, Mohamed A. Raslan ${ }^{4}$ \\ and Kamal U. Sadek ${ }^{5}$ \\ ${ }^{1}$ Department of Nitrogen, KIMA Company, 81514, ${ }^{2}$ Department of Electrical Power \\ and Machines, University of Aswan, Aswan, Egypt, $81542{ }^{2}$ College of Engineering- \\ Wadi Aldawaser University of Prince Sattam bin Abdulaziz, 11991,Saudi Arabia, \\ dr.ziad.elhalwany@gmail.com, ${ }^{3}$ Department of Polymer \& Pigments, National \\ Research Centre, Cairo, 12622,nehad.naem@yahoo.com, ${ }^{4}$ Department of Chemistry, \\ Faculty of Science,University of Aswan, Aswan, 81528, raslanma47@yahoo.com and \\ ${ }^{5}$ Department of Chemistry, University of Minia, Minia,Egypt,kusadek@yahoo.com
}

\begin{abstract}
$T^{1}$ HIS WORK focused on using silica fume (by product) and quartz (industrial waste) in manufacture of ferrosilicon alloys in Egyptian chemical industries company (KIMA), in Aswan, Egypt. To reinforce the properties of Nitrile rubber, reduce cost and save the environment from industrial waste. Preparation rubber composites by addition different concentrations from silica fume filler (byproduct) and quartz filler (industrial waste). Investigation on the insulation properties of nitrile rubber composites by measurement of flashover voltage for unfilled nitrile rubber (blank) and nitrile rubber composites with silica fume filler and quartz filler. The measurement of flashover voltage for nitrile rubber composites occurred in different conditions (dry, wet, salinity and acidity). The effect of silica fume filler and quartz filler on mechanical properties of nitrile rubber was studied by investigation on elongation at break for nitrile rubber composites and also tensile strength. Studied the effect of hybrid filler on enhancement of electrical properties and mechanical properties of nitrile rubber, by adding different concentrations of mica filler on the samples showed the least enhancement in insulation properties of nitrile rubber composites in case of silica fume and quartz filler. And also study the morphology of nitrile rubber composites.
\end{abstract}

Keywords: Acrylonitrile-butadiene rubber (NBR), Dielectric properties, Mechanical properties, Quartz, Silica fume, Polymer insulators, Hybrid filler.

\section{Introduction}

Egyptian chemical industries company (KIMA) is considered from the biggest companies in Egypt for the manufacture of fertilizer and chemical industries. KIMA was founded in 1963 in Aswan city in Egypt. The main products in KIMA are the Ammonium nitrate used in medical and industrial purposes and manufacture of ferrosilicon alloys. The secondary products silica fume used for cement industry. Silica fume is a by-product of manufacture of ferrosilicon alloys in KIMA. It is known a micro silica amorphous powder; it was added to concrete to enhance some of properties such as compressive strength and abrasion resistance. Quartz is the raw material in the manufacture of ferrosilicon alloys and the under size of $5 \mathrm{~cm}$ is waste. It can grind to reach Nano particle size. Synthetic elastomers have poor properties and not self-reinforcing elastomers. For example, nitrile elastomers do not crystallize when they are stretched, and they need reinforcing fillers to enhance their properties such as tensile strength and tear resistance. Fillers play an active role in rubber matrix, since it enhances the electrical, mechanical and thermal properties. A lot of studies worked on enhancement the properties of rubber by using different types of fillers and the results showed a good reinforcement in the mechanical and electrical characteristic of rubber composites [1-6].

*Corresponding author e-mail: mst.dief@gmail.com 
The elastomers have several applications in different fields, before the utilization requires enhancements to its properties because of the deficiency in modulus and strength. So that, in fact a lot of rubber products are composites manufactured from an elastomeric matrix, filler have the active role in determining maximum performance of the filled rubber compounds [6-9].

Fillers reduce the cost of the materials and also enhance the electrical, mechanical and thermal properties of the polymers. Mica filler is considered from the best fillers since show enhancement in dielectric properties of polymer in insulators industry and also enhanced its mechanical properties, this changed the world in insulators industry by using polymer insulator as alternative ceramic insulators and showed good results. Silica filler was showed a good reinforcement in rubber industry. Silica fume is a secondary produce of the silicon smelting process. It is used to produce silicon metal and ferrosilicon alloys by reducing quartz in an electric arc furnace. Silica fume is characterized by its small spherical particles, very high surface area and has a high content of silicon dioxide $\left(\mathrm{SiO}_{2}\right)$ [10-13]. The degree of reinforcement provided by filler depends on a number of variables like the size of particle, particle shape, density, chemical activity and the distribution of filler in rubber matrix and these properties different from filler to filler so that the reinforcement of rubber different also. From the most wide filler in rubber industry, carbon black (channel and furnace type), zinc oxide, clays, calcium carbonates, silicates and titanium oxide. Nitrile rubber is a copolymer of butadiene and acrylonitrile. Nitrile rubber (NR) has irregular chain structure and do not crystallize on stretching. NR is characterized by good mechanical properties. Oil resistance, the most important property of NR, is the reason for the extensive use of these rubbers for manufacturing oil seals, hoses, shoe soles and tubes. But it has moderate insulating properties. According to the importance on Nitrile rubber (NR) and have distinguishing properties qualified it to introduce a lot of industries, many recent studies occurred on Nitrile rubber to reinforce its mechanical and electrical properties by using different fillers like silica, different types of carbon blacks, calcium carbonate and clay [14-16]. These researches showed reinforcement in properties of Nitrile rubber and the studies continue to improve the performance of Nitrile rubber and enhanced its electrical, mechanical and thermal properties Egypt.J.Chem. 60 , No.5 (2017) and the trends in the previous period seeks to use the industrial waste from some industries as filler to reinforce rubber properties, reduce cost and save the environment [17-21]. Polymers are in general insulated material with low values of electrical conductivity and low value of dielectric constant. But the value of electrical conductivity or dielectric constant can be increased by the type of fillers are added, so that the polymers widely used in electrical application. From the importance electrical test occurred for rubber after addition of filler to estimate the dielectric performance is flashover voltage and this flashover occurred at the maximum voltage at which an electric discharge occurs between two electrodes and by increasing the flashover voltage increase the dielectric properties of polymers [22-23].

The emphasis in this work is on the insulation properties of Nitrile rubber composites loaded with different concentrations of silica fume filler and quartz filler. Included the flashover voltage for rubber composites in different conditions (dry, wet, salinity and acidity) and also the mechanical properties of these composites are discussed such as tensile strength and elongation at break. Moreover the effect of hybrid filler on the insulation properties, tensile strength and elongation at break of rubber composites are also taken into consideration.

\section{Materials and Experimental}

\section{Materials}

Nitrile rubber (NR) with specific acrylonitrile content of $32 \%$, specific gravity $1.17 \pm 0.005 \mathrm{~g} / \mathrm{cm}^{3}$; was provided by Bayer AG, Germany.N-cyclohexyl2-benzothiazole sulphenamide (CBS), pale gray powder, with specific gravity of $1.27-1.31 \mathrm{~g} /$ $\mathrm{cm} 3$ at room temperature $\left(25 \pm 1{ }^{\circ} \mathrm{C}\right)$, melting point $95-100^{\circ} \mathrm{C}$ was used as an accelerator .Zinc oxide and stearic acid were used as activators with specific gravity at $15^{\circ} \mathrm{C}$ of $5.55-5.61 \mathrm{~g} / \mathrm{cm}^{3}$ and $0.90-0.97 \mathrm{~g} / \mathrm{cm}^{3}$, respectively. Elemental sulfur, fine pale yellow powder, with specific gravity of $2.04-2.06 \mathrm{~g} / \mathrm{cm}^{3}$ at room temperature was used as a vulcanizing agent. Dioctyl phthalate (DOP) was used as a plasticizer with specific gravity $0.991 \mathrm{~g} / \mathrm{cm}^{3}$ and boiling point $=384{ }^{\circ} \mathrm{C}$. All the rubber ingredients were of commercial grades, purchased from Aldrich Co., Germany.

Quartz introduces in manufacture of ferrosilicon alloys and the under size $3 \mathrm{CM}$ is industrial waste, it grinded by Fritsch pulverisette mill reached to $20 \mu$ particle size and it has been 
examined using XRF is $\mathrm{SiO}_{2}=98.5 \% ; \mathrm{Fe}_{2} \mathrm{O}_{3}=$ $0.3 \% ; \mathrm{CaO}=0.3 \% ; \mathrm{MgO}=0.10 \% ; \mathrm{Al}_{2} \mathrm{O}_{3}=0.7 \%$.

Silica fume is a by-product of manufacture of ferrosilicon alloys in KIMA company in Aswan city in Egypt has been examined using XRF is $\mathrm{SiO}_{2}$ $=95 \% ; \mathrm{Fe}_{2} \mathrm{O}_{3}=1.5 \% ; \mathrm{CaO}=0.8 \% ; \mathrm{MgO}=1.0 \%$; $\mathrm{Al}_{2} \mathrm{O}_{3}=1.5 \% ; \mathrm{C}=1.05 \% ; \mathrm{K}_{2} \mathrm{O}, \mathrm{Na}_{2} \mathrm{O}=2 \%$.

Mica is used principally in the electronic and electrical industries, has been examined using $\mathrm{XRF}$ is $\mathrm{SiO}_{2}=75.18 \% ; \quad \mathrm{Fe}_{2} \mathrm{O}_{3}=3.18 \%$; $\mathrm{CaO}=0.39 \% ; \quad \mathrm{MgO}=0.37 \% ; \quad \mathrm{Al}_{2} \mathrm{O}_{3}=11.33 \%$; $\mathrm{Na}_{2} \mathrm{O}=3.43 \% ; \mathrm{K}_{2} \mathrm{O}=3.76 \%$.

TABLE 1. Preparation of nitrile rubber composites.

\section{Preparation of samples}

The preparation of Nitrile rubber (NR) composites loaded with quartz and silica fume are shown in Table 1 . The composites were manufactured on two rolls-mixing mills (outside diameter $470 \mathrm{~mm}$, working distance $300 \mathrm{~mm}$, speed of slow roll $24 \mathrm{rpm}$ and friction ratio of (1:1.4) in accordance with ASTM D3182-07. The rubber composites were vulcanized in an electrically heated hydraulic press at $152 \pm 1{ }^{\circ} \mathrm{C}$ and at a pressure of about $4 \mathrm{MPa}$.

\begin{tabular}{ll}
\hline Ingredient, phr*) & \\
\hline Nitrile rubber (NR) & 100 \\
Stearic acid & 2 \\
Zinc Oxide (ZnO) & 5 \\
Dioctyl phathalate ( DOP) & 3 \\
S (sulfur) & 2 \\
N-cyclohexyl-2-benzothiazole sulphenamide (CBS) & 1 \\
Quartz & $0,5,10,15,20,25,30,35,40,45,50$ \\
Silica fume & $0,5,10,15,20,25,30,35,40,45,50$ \\
\hline "phr: part per hundred rubber &
\end{tabular}

phr: part per hundred rubber

\section{Technique}

\section{Flashover voltage}

The AC $(50 \mathrm{~Hz})$ high voltage supplied from a single phase high voltage auto transfer $\quad(100 \mathrm{KV}-$ 15KVA). Cylinder electrodes were made of copper with $1 \mathrm{~cm}$ diameter. The electrode was fixed to the samples, one at the top and the other at the bottom carefully to ensure a good distribution on NR pattern. The experiments were carried out in a high voltage laboratory.

\section{Mechanical properties}

The rheometric behavior of Nitrile rubber (NR) composites was determined using an oscillating disc, Monsanto rheometer model 100, according to ASTM D2084. The vulcanized sheets prepared for mechanical tests were cut into five individual dumb-bell shaped specimens by a steel die of constant width $(4 \mathrm{~mm})$. The thickness of the test specimen was determined by a gauge calibrated in hundredths of a millimeter. A working part of scale $15 \mathrm{~mm}$ was chosen for each test specimen. The mechanical properties (e.g. tensile strength, elongation at break) of Nitrile rubber composites were determined according to standard methods using an electronic Zwick tensile testing machine, model 1425, in accordance with ASTM D412.

\section{Scanning electron microscopy (SEM)}

Scanning Electron Microscope (SEM) model JSM T20 (JEOL, Japan) was used to characterize the composites morphology. SEM was performed by mounting the polymer blend samples on a standard specimen tube, and then depositing a very thin layer of gold on the samples.

\section{Results and Discussion}

\section{Electrical testing}

From the important electrical testing occurred on insulators to measure the insulation properties, flashover voltage, flashover voltage is the voltage at which an electric discharge occurs between two electrodes that are separated by an insulator, that value depends on whether the insulators surface is dry or contaminated by External influences such as water, salinity and acidity. And measured flashover voltage for Nitrile rubber (NR) composites in dry surface and flashover voltage for Nitrile rubber composites for surface contaminated by water, sodium chloride $10 \%$ wt. and nitric acid $30 \%$. The specimens of Nitrile rubber composites are created as circular specimens having $5 \mathrm{~cm}$ diameter and thickness $1 \mathrm{~mm}$. Flashover voltage was measured for Nitrile rubber composites by the electrode was fixed to the specimens on the top and the other at the bottom carefully to ensure a good contact. The Egypt.J.Chem. 60, No.5 (2017) 
high voltage between two electrodes increased gradually from zero by constant rate $2 \mathrm{KV} / \mathrm{sec}$ until the flashover voltage (Fig. 1).

Flashover voltage for NR composites on dry surface

The effect of addition different concentrations of quartz and silica fume on flashover voltage of nitrile rubber (NR) on dry surface as illustrated in Fig.2, and showed the comparison between flashover voltages for NBR blank ( 0 phr filler) and flashover voltages for NR filled with different concentrations of quartz and silica fume.

Figure 2 illustrated flashover voltage of NR and NR filled with silica fume and quartz. The results showed that the addition of silica fume filler and quartz filler to NR enhanced the insulation properties of NR. The data given for flash over voltages as shown in Fig. 2, indicates that the insulation property of NR filled with quartz is better than insulation property of NR filled with silica fume in high concentrations of filler. But the insulation property of NR with low concentration of silica fume is better than the insulation property of NR in low concentration of quartz in dry condition.

Flashover voltage for NR composites on wet surface

The flashover voltage on the insulation surfaces which occurred by immersing the specimens in water and measured the flashover voltage for NR and NR composites on wet surface is illustrated in Fig. 3.
The results in Fig. 3, showed the addition of silica fume filler to NR enhanced the insulation properties and the concentration $(10 \mathrm{phr})$ showed the highest flashover voltage of NR composites compared with NR blank, silica fume concentration at $(45 \mathrm{phr})$ showed the lowest flashover voltage of NR composites. Flashover voltage of NR composites in case quartz filler showed enhancement in insulation properties, the concentration ( $50 \mathrm{phr}$ ) of quartz showed the highest flashover voltage of NR composites and the concentration ( $25 \mathrm{phr}$ ) of quartz filler showed the lowest flashover voltage. On the other hand, the insulation property of NR filled with quartz filler is better than silica fume filler.

Flashover voltage for NR composites on surface contaminated by sodium chloride solution $10 \% \mathrm{wt}$.

Specimens of NR composites immersed in sodium chloride $10 \%$ wt. to study the effect of salinity on insulation properties of NR composites. Flashover voltages of NR and NR composites in salinity condition are illustrated in Fig. 4.

Figure 4 illustrated the addition of silica fume to NR enhanced the insulation properties. The best concentration of silica fume filler added to NR is $(10 \mathrm{phr})$ since it showed the best enhancement in insulation properties for NR. The comparison between the insulation properties of NR with silica fume filler and quartz filler the results of flashover voltage for NR composites the insulation properties of NR composites enhanced with low concentrations of silica fume but enhanced with high concentrations of quartz filler in salinity condition.

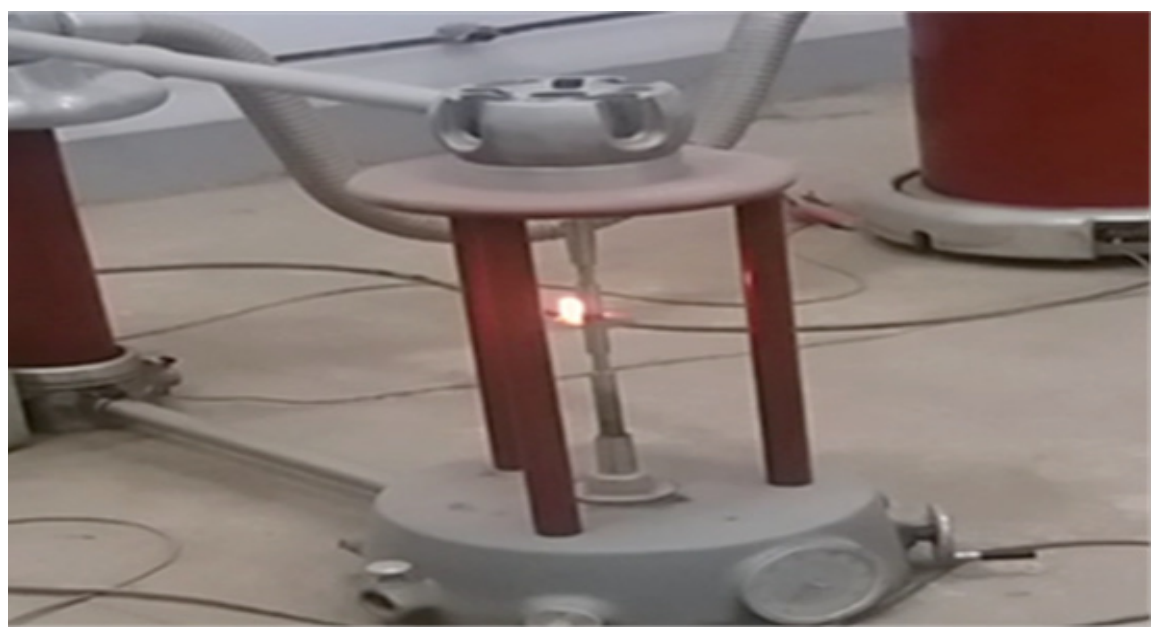

Fig. 1 . Specimen under effect of flashover voltage test. 


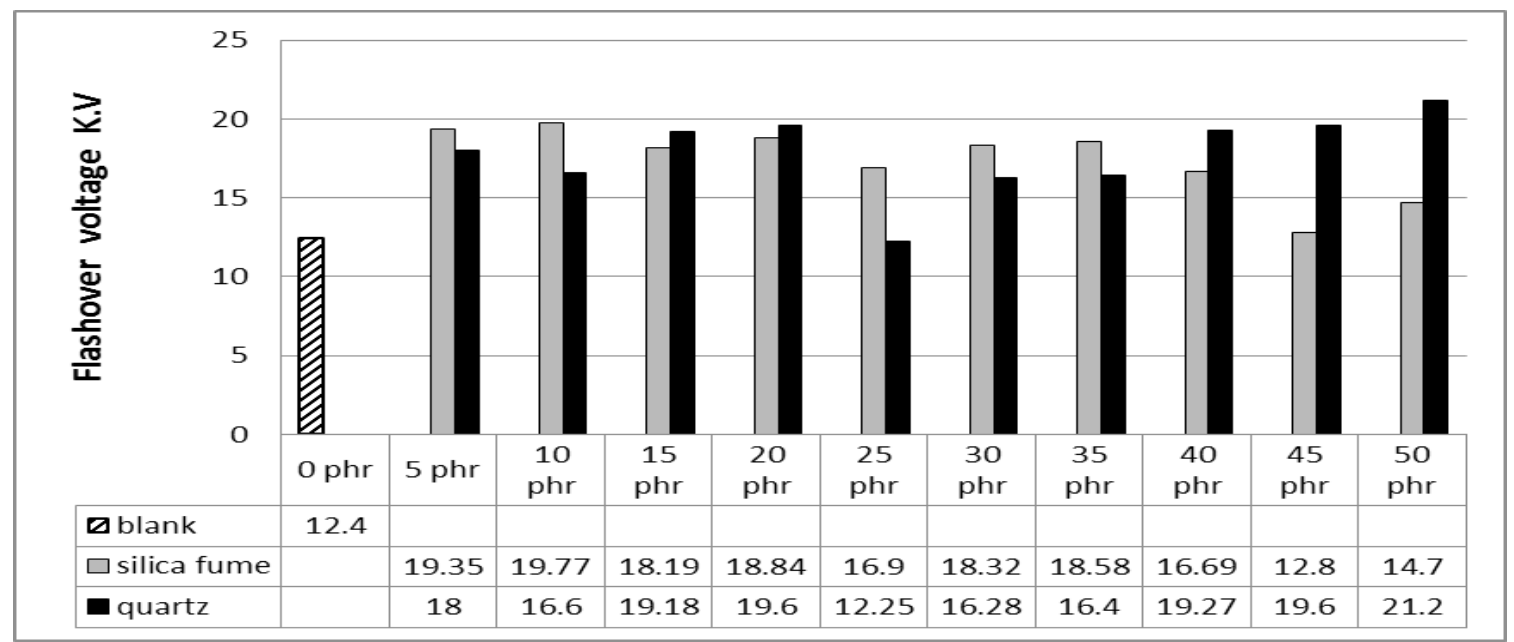

Fig. 2. The flashover voltage of blank NR and flashover voltage of NR filled with silica fume and quartz on dry surface.

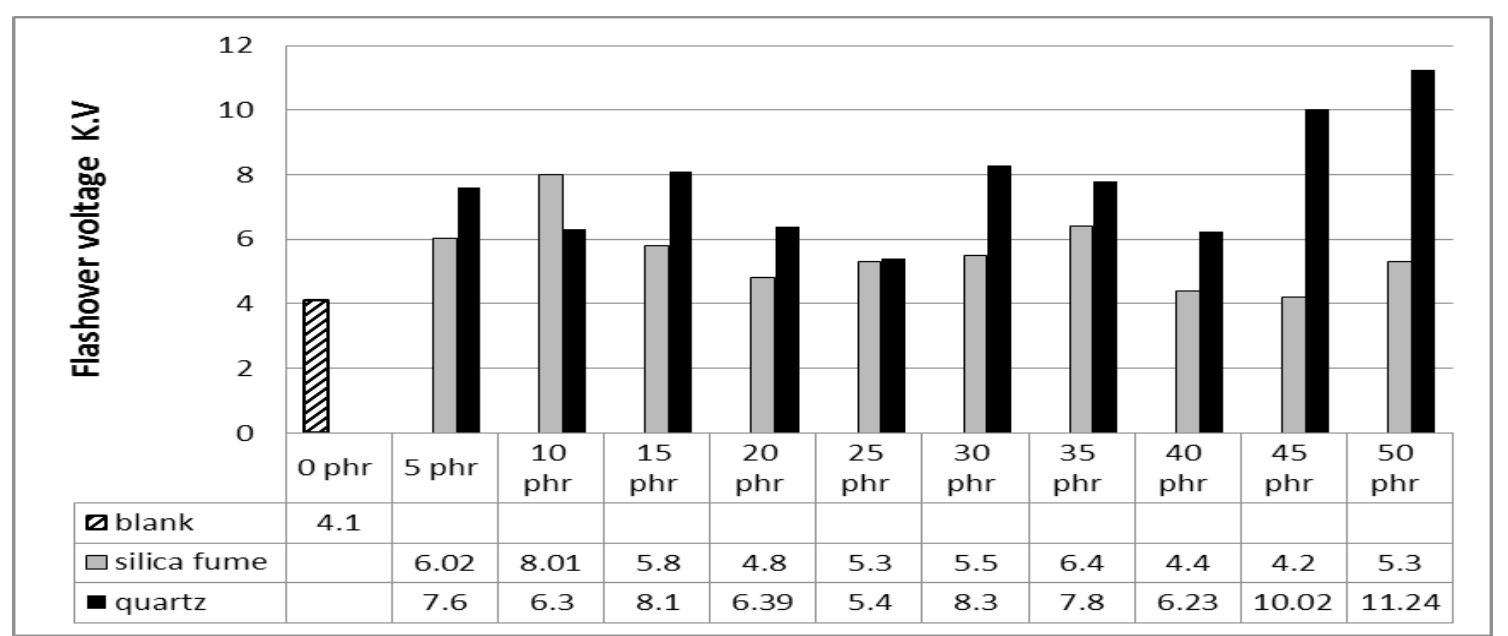

Fig. 3. The flashover voltage of blank NR and flashover voltage of NR filled with silica fume and quartz on wet surface.

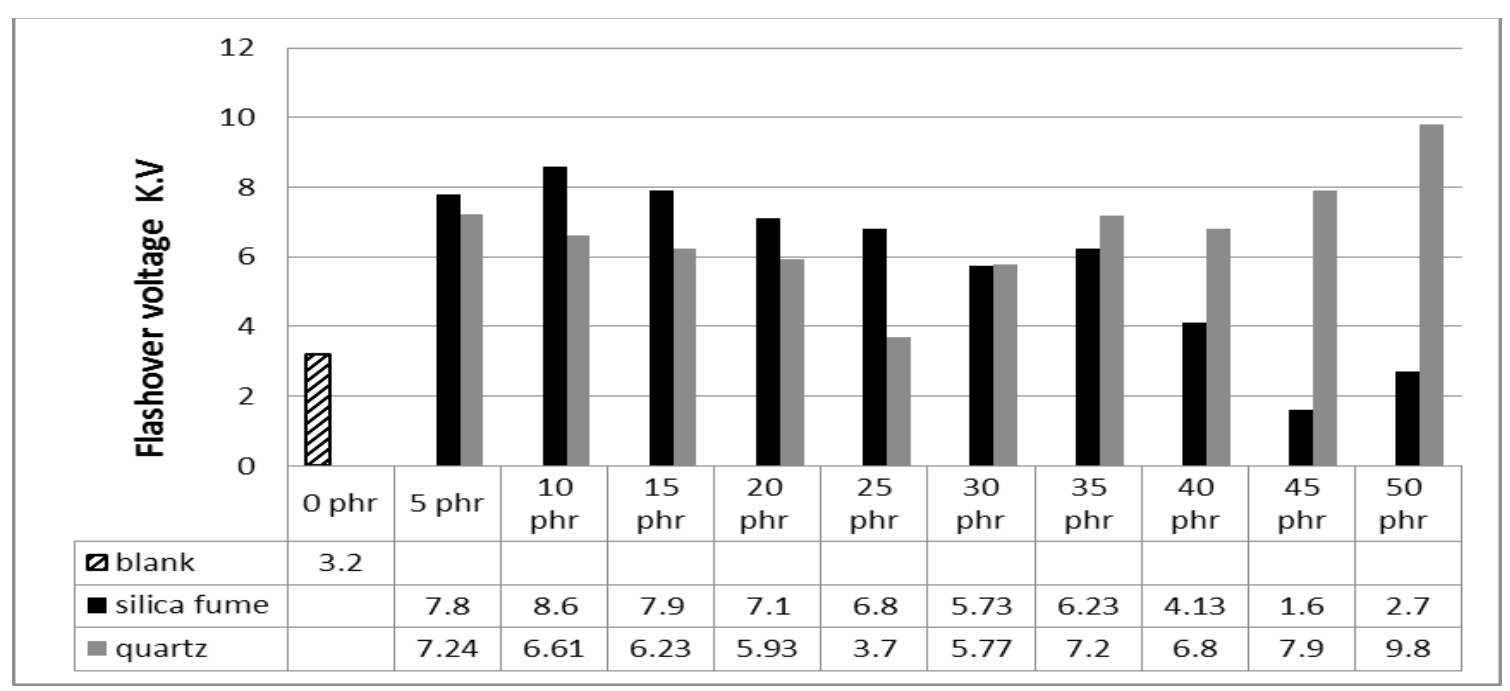

Fig. 4. The flashover voltage of blank NR and flashover voltage of NR filled with silica fume and quartz on surface contaminated by sodium chloride $10 \%$ wt. 
Flashover voltage for NR composites on surface contaminated by nitric acid 30\%.

Specimens of NBR composites immersed in nitric acid $30 \%$ and measured flashover voltage for NBR and NBR filled with silica fume and quartz on surface contaminated with nitric acid $30 \%$. The results showed breakdown voltage for the composites this due to that the nitric acid $30 \%$ lost the insulation properties for NBR blank and also NBR filled with silica fume and quartz filler.

The effect of Mica filler on insulation properties of NR composites

From the results of flashover voltage of NR composites filled with various concentrations of silica fume filler and quartz filler showed that the least enhancement in insulation properties of NR composites in case of silica fume at concentration (45 phr) and in case of quartz filler at concentration (25 phr). We studied the effect of addition $(5,10$, $15 \mathrm{phr}$ ) of mica filler on the insulation properties of NR filled with (45 phr) of silica fume filler and NR filled with (25 phr) of quartz filler.

Flashover voltage of NR composites with (silica fume and mica)

Table 2 shows flashover voltage of NR composites filled with hybrid filler (various concentration of mica filler with (45 phr) of silica fume) in different condition (dry, wet, salinity and acidity).

The results in Table 2 illustrate that the addition of mica $(5,10$ and $15 \mathrm{phr})$ causes enhancement in the insulation property. Figure 5 shows flashover voltage of NR composites filled with hybrid filler (mica filler and silica fume filler) in dry condition. The addition of mica filler to NR composites filled with (45 phr) silica fume filler enhanced the insulation properties of NR composites and the concentration of mica (15 phr) showed the best enhancement in insulation properties of NR composites in dry condition and in all condition (wet, salinity and acidity) as shown in Table 2

Flashover voltage of NR composites with (quartz and mica)

The flashover voltage of NR composites filled with various concentrations of mica filler and (25 phr) quartz in different conditions ( dry, wet, salinity and acidity) shown Table 3

From Table 3 Illustrated that the addition of mica filler to NR composites filled with ( $25 \mathrm{phr})$ of quartz filler enhanced the insulation properties of NR composites in different condition (dry, wet, salinity and acidity). Figure 6 illustrates flashover voltage of NR composites filled with hybrid filler (mica filler and quartz filler) in dry condition, the results showed the addition different concentrations of mica filler to NR composites filled with (25 phr) quartz filler enhanced the insulation properties of NR composites in dry condition and The concentration of mica filler (15 phr) added to NR composites showed the best enhancement in insulation properties in dry condition and others condition (wet, salinity and acidity).

TABLE 2. Flashover voltage of NR composites filled with hybrid filler (mica filler and silica fume filler).

\begin{tabular}{lcccccc}
\hline Sample & $\begin{array}{c}\text { Concentration of } \\
\text { silica fume }\end{array}$ & $\begin{array}{c}\text { Concentration } \\
\text { on mica }\end{array}$ & \multicolumn{4}{c}{ Flashover voltage of NR composites } \\
\hline NR 1 & $45 \mathrm{phr}$ & $0 \mathrm{phr}$ & $12.8 \mathrm{KV}$ & $4.2 \mathrm{KV}$ & $1.9 \mathrm{KV}$ & $0 \mathrm{KV}$ \\
NR 2 & $45 \mathrm{phr}$ & $5 \mathrm{phr}$ & $13 \mathrm{KV}$ & $11 \mathrm{KV}$ & $7 \mathrm{KV}$ & $2 \mathrm{KV}$ \\
NR 3 & $45 \mathrm{phr}$ & $10 \mathrm{phr}$ & $11 \mathrm{KV}$ & $8 \mathrm{KV}$ & $3.4 \mathrm{KV}$ & $0 \mathrm{KV}$ \\
NR 4 & $45 \mathrm{phr}$ & $15 \mathrm{phr}$ & $22 \mathrm{KV}$ & $18 \mathrm{KV}$ & $13 \mathrm{KV}$ & $7 \mathrm{KV}$ \\
\hline
\end{tabular}

TABLE 3 . Flashover voltage of NR composites filled with hybrid filler (mica filler and quartz filler).

\begin{tabular}{|c|c|c|c|c|c|c|}
\hline \multirow[t]{2}{*}{ Sample } & \multirow{2}{*}{$\begin{array}{l}\text { Concentration of } \\
\text { quartz filler }\end{array}$} & \multirow{2}{*}{$\begin{array}{l}\text { Concentration } \\
\text { on mica filler }\end{array}$} & \multicolumn{4}{|c|}{ Flashover voltage of NR composites } \\
\hline & & & Dry & Wet & Salinity & Acidity \\
\hline NR 5 & $25 \mathrm{phr}$ & $0 \mathrm{phr}$ & $12.25 \mathrm{KV}$ & $6.3 \mathrm{KV}$ & $3.7 \mathrm{KV}$ & $0 \mathrm{KV}$ \\
\hline NR 6 & $25 \mathrm{phr}$ & $5 \mathrm{phr}$ & $17 \mathrm{KV}$ & $14 \mathrm{KV}$ & $10 \mathrm{KV}$ & $4 \mathrm{KV}$ \\
\hline NR 7 & $25 \mathrm{phr}$ & $10 \mathrm{phr}$ & $16 \mathrm{KV}$ & $13 \mathrm{KV}$ & $8 \mathrm{KV}$ & $2 \mathrm{KV}$ \\
\hline NR 8 & $25 \mathrm{phr}$ & $15 \mathrm{phr}$ & $21 \mathrm{KV}$ & $17 \mathrm{KV}$ & $12 \mathrm{KV}$ & $6 \mathrm{KV}$ \\
\hline
\end{tabular}

Egypt.J.Chem. 60 , No.5 (2017) 


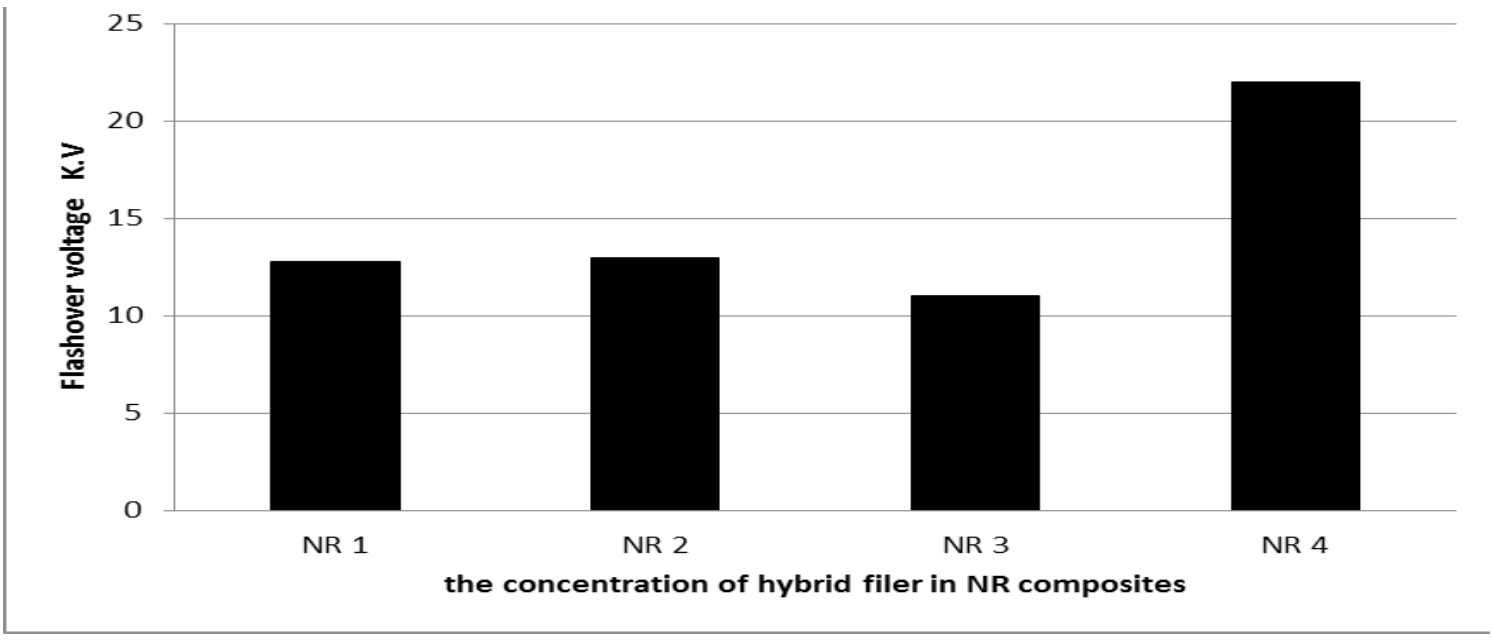

Fig. 5. flashover voltage of NR composites filled with hybrid filler (mica filler and silica fume filler) in dry condition.

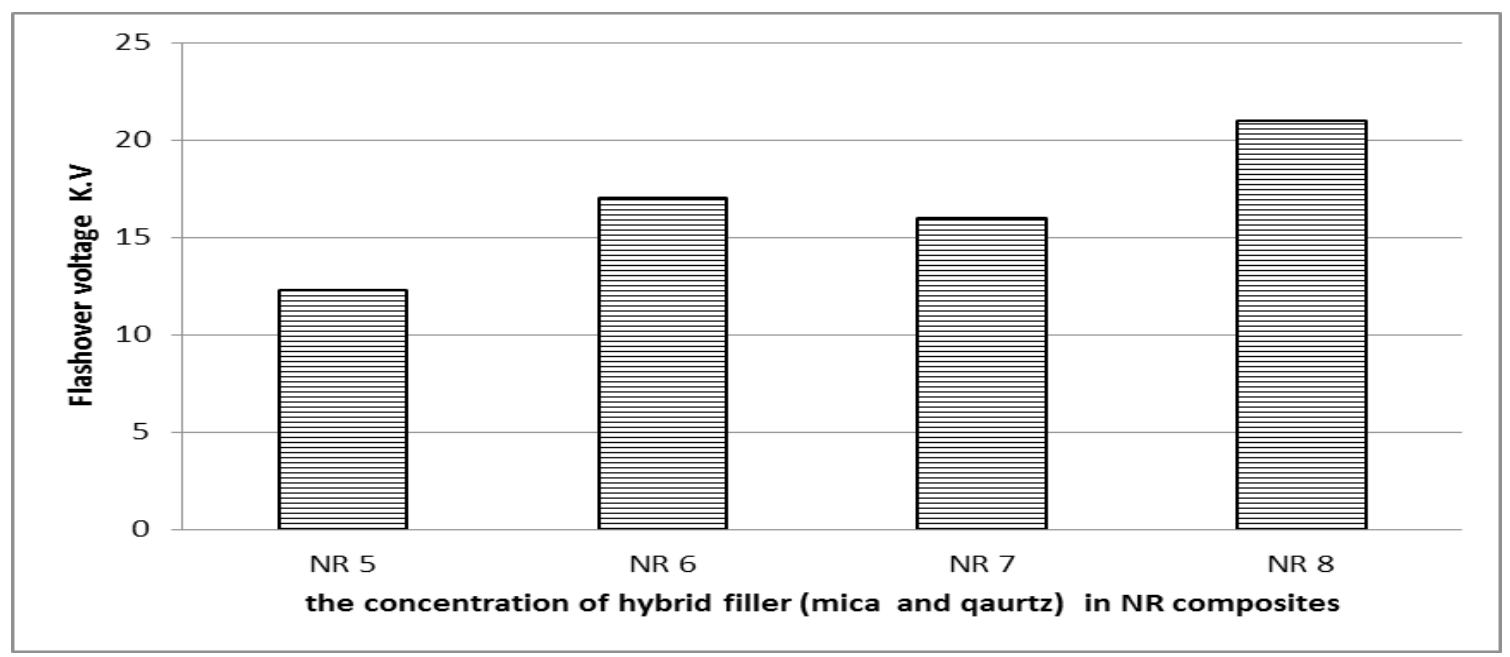

Fig. 6 flashover voltage of NR composites filled with hybrid filler (mica filler and quartz filler) in dry condition.

\section{Mechanical testing}

The effect of adding different concentrations from silica fume and quartz on mechanical properties of NR like tensile strength and elongation at-break is shown in the following.

Tensile strength of Nitrile rubber (NR) composites

The effect of adding different concentrations of silica fume filler and quartz filler on tensile strength of NR is clarified in Fig. 7; the results showed that the addition of different concentrations from silica fume filler to NR enhanced the tensile strength. By increasing the concentration of silica fume filler to NR increases tensile strength. And the best concentration of silica fume filler gives the best enhancement in tensile strength at concentration $(\mathrm{C} 10=50 \mathrm{phr})$. But the addition of different concentrations of quartz filler to NR not enhanced tensile strength compared with tensile strength of NR blank. Figure 7 illustrated that the addition of silica fume filler to NR enhanced tensile strength and quartz not enhanced tensile strength.

\section{Elongation at break of NR composites}

The effect of adding different concentrations of silica fume filler and quartz filler on elongation at break of NR is illustrated in fig. 8, and also shows the comparison between elongation at break of NR (blank) and elongation at break of NR loaded with various concentrations of silica fume and quartz. 


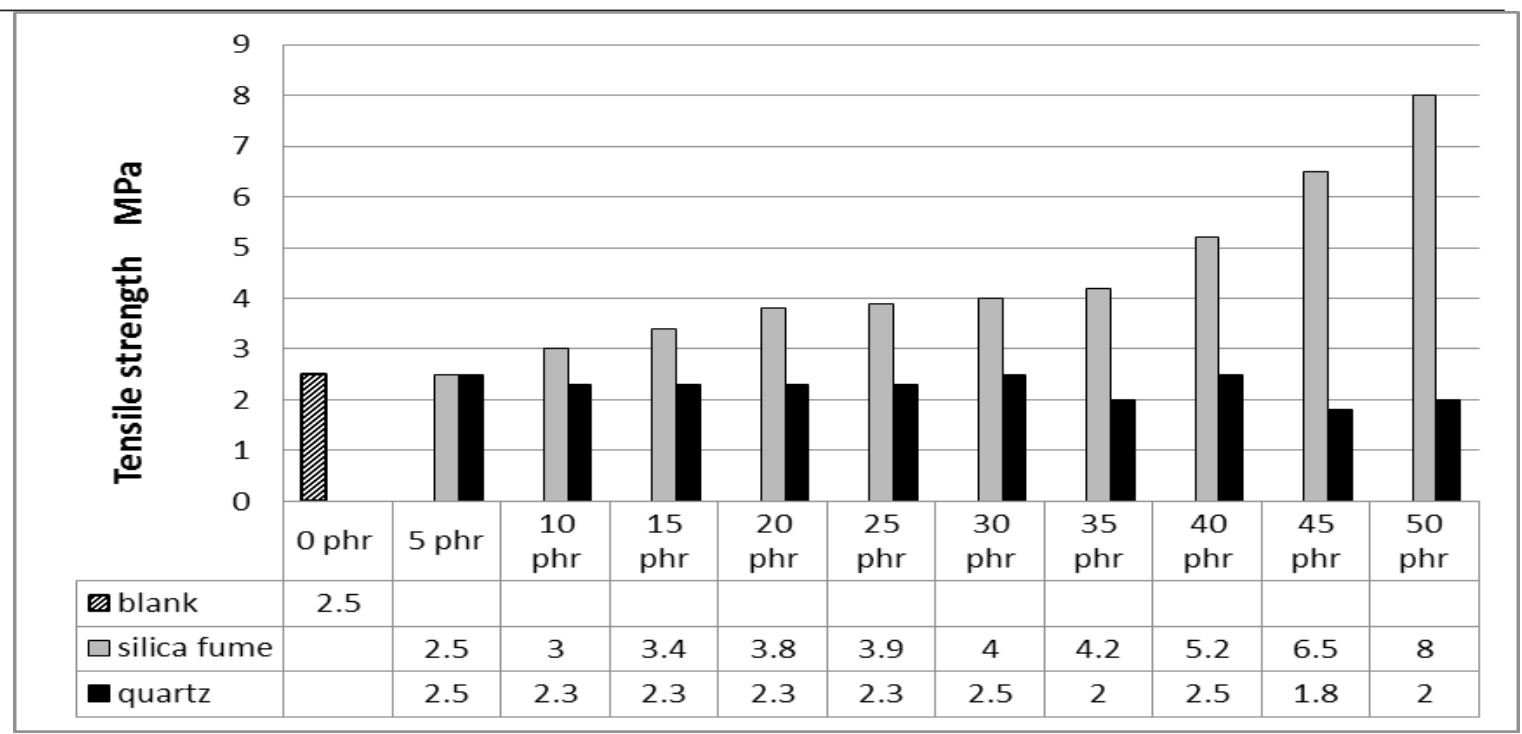

Fig.7 . Tensile strength of NR blank and tensile strength of NR filled with different concentrations of silica fume and quartz.

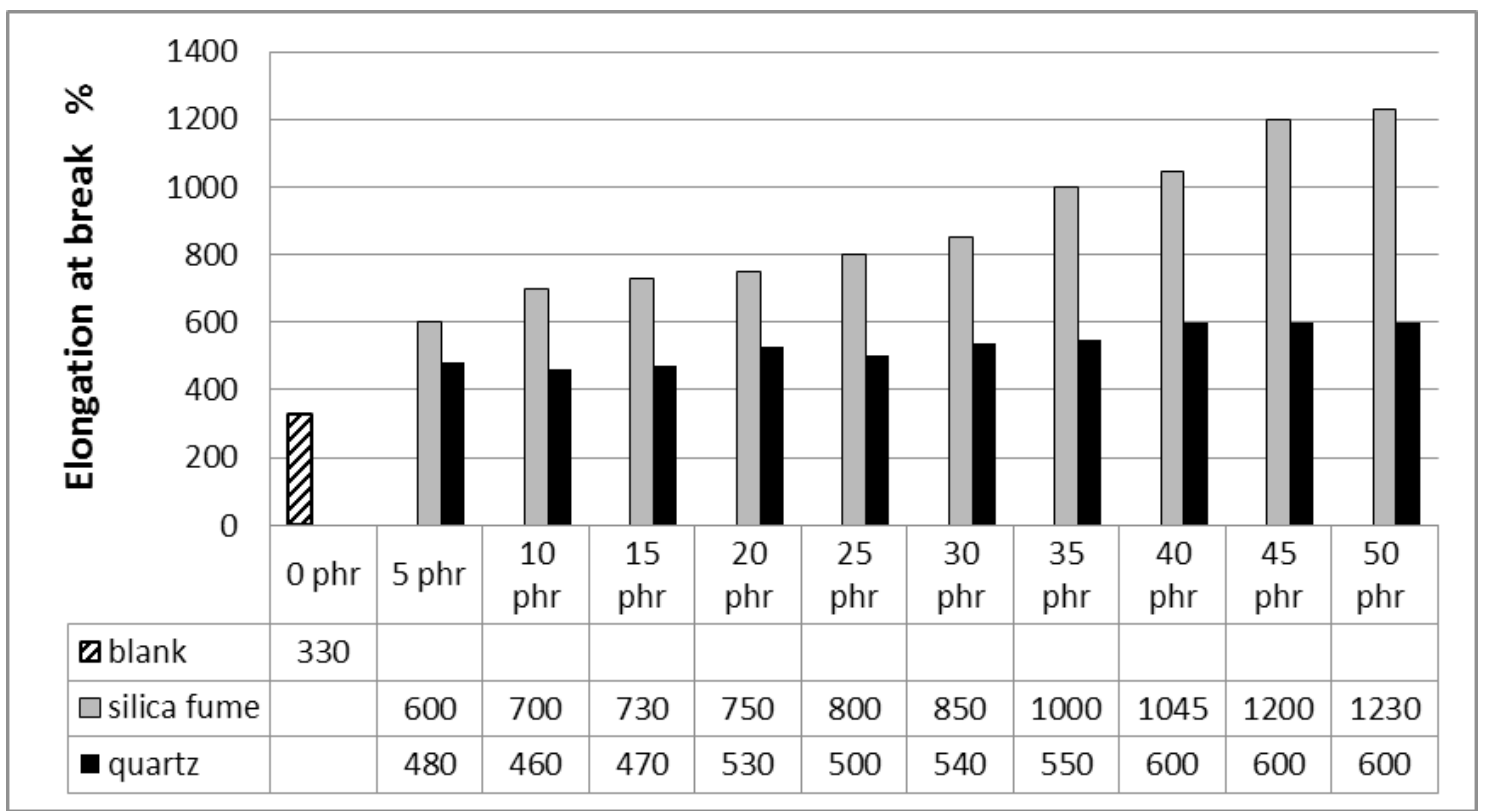

Fig. 8 . Elongation at break of NR (Blank) and elongation at break of NR loaded with various concentrations of silica fume and quartz.

Figure 8, illustrated the effect of adding different concentrations from silica fume filler and quartz filler on elongation at break of Nitrile rubber (NR), The results illustrated the addition of silica fume filler and quartz filler to NR enhanced elongation at break of NR. The addition of different concentrations of silica fume filler enhanced the elongation at break of NR, by increa sing the concentration of silica fume filler increases the enhancement of elongation at break of NR compared with NR blank and the concentration of silica fume (50 $\mathrm{phr}$ ) give the best enhancement in elongation at break of NR. Figure 8 showed also the addition of different concentrations of quartz to NR enhanced elongation at break of NR and concentrations of quartz at (40 phr), (45 phr), (50 phr) give the best enhancement in elongation at break. According to Fig. 8 the addition of silica fume filler to NR enhanced elongation at break 
of NR better than quartz.

The effect of addition mica filler on mechanical properties of $N R$

The addition of mica filler to NR filled with (45 phr) of silica fume filler and NR filled with (25 phr) quartz filler showed enhancement in electrical properties. Figure $9 \& 10$ show the effect of adding different concentrations of mica filler $(5,10,15$ phr) on tensile strength of NR composites and fig. 9,10 illustrate the effect of addition mica filler on elongation at break of C9 and Q5.

Figure 9 shows the addition of mica filler on NR composites filled with silica fume filler (45 phr) enhanced tensile strength of NR and the concentration of mica filler (15 phr) added to NR composites shows the best enhanced in tensile strength, fig. 10 shows also the addition of mica filler to NR composites filled with quartz filler (25 phr) enhanced tensile strength of NR and by increasing the concentration of mica filler increase of enhancement in tensile strength of NBR and the concentration of mica filler (15 phr) shows the best enhancement in tensile strength of NR composites.

Figure 11 illustrates the addition of different concentrations of mica filler to NR filled with silica fume filler ( $45 \mathrm{phr}$ ) and results illustrated that the addition of mica filler enhance elongation at break of NR, the concentration of mica filler (15 phr) showed the best enhancement of elongation at break of NR composites. Figure 12 shows the addition of different concentrations of mica filler to NR filled with quartz filler (25 phr) filler and results illustrated that the addition of mica filler enhance elongation at break of NR, the concentration of mica filler ( $15 \mathrm{phr}$ ) showed the best enhancement of elongation at break of NR composites.

\section{Scan electron microscopy}

Scanning electron micrographs for selected content of NR/silica fume and NR/ quartz are given in Fig. 13, from these figures, it is seen that fine distribution of both fillers was detected at 20 and $50 \mathrm{phr}$ filler loading. This fine distribution was the cause of the performance in both electrical and the mechanical properties of such composites. Otherwise the aggregation of filler particles which was observed in the sample containing $50 \mathrm{phr}$ was the cause of the plateau obtained in those properties. The rubber-filler adhesion is increased and in high concentration due to the decrease in the tendency of the filler particles to agglomerate.

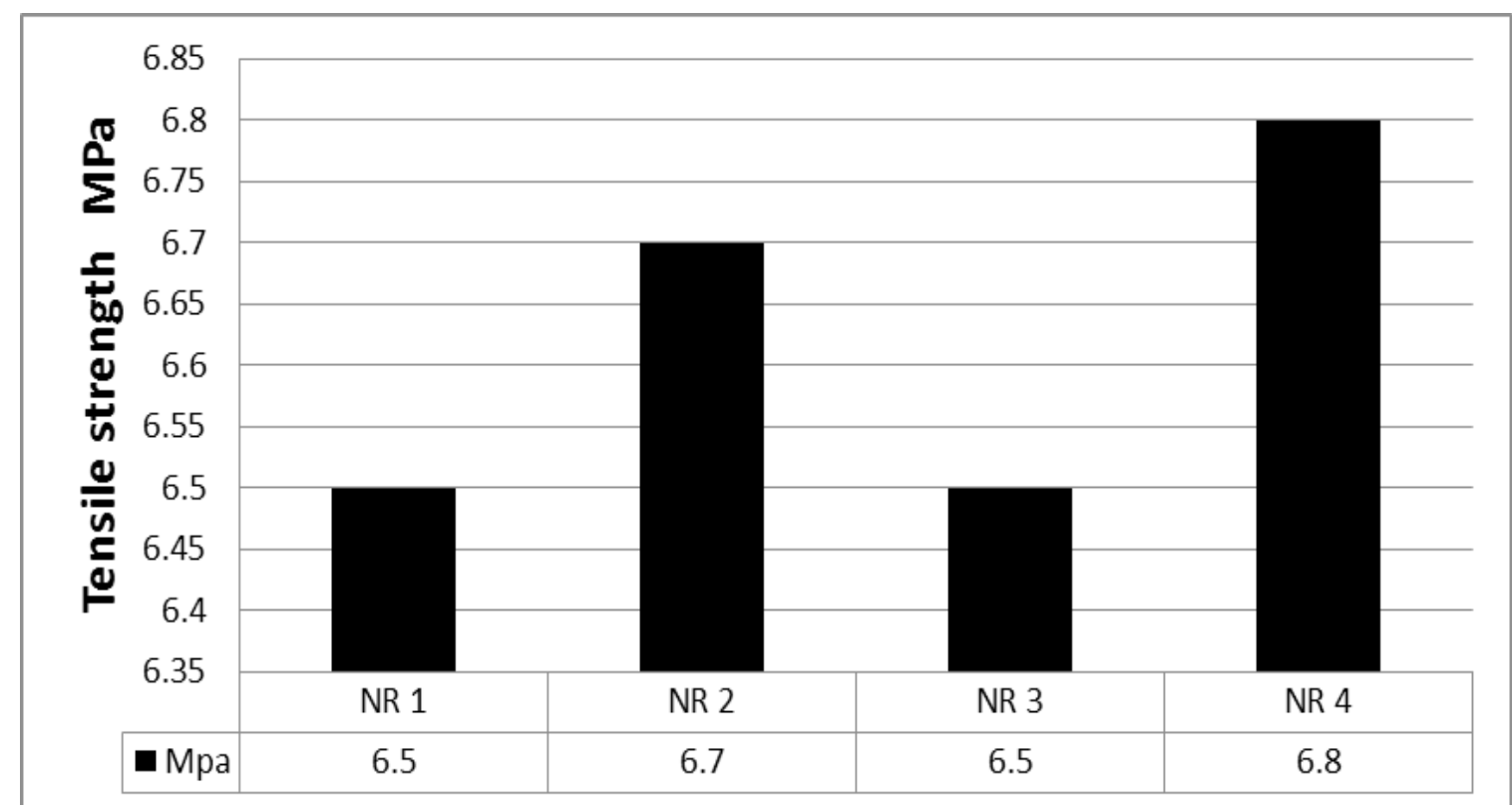

Fig. 9. The effect of addition hybrid filler (mica filler and silica fume filler) on tensile strength of NR composites . 


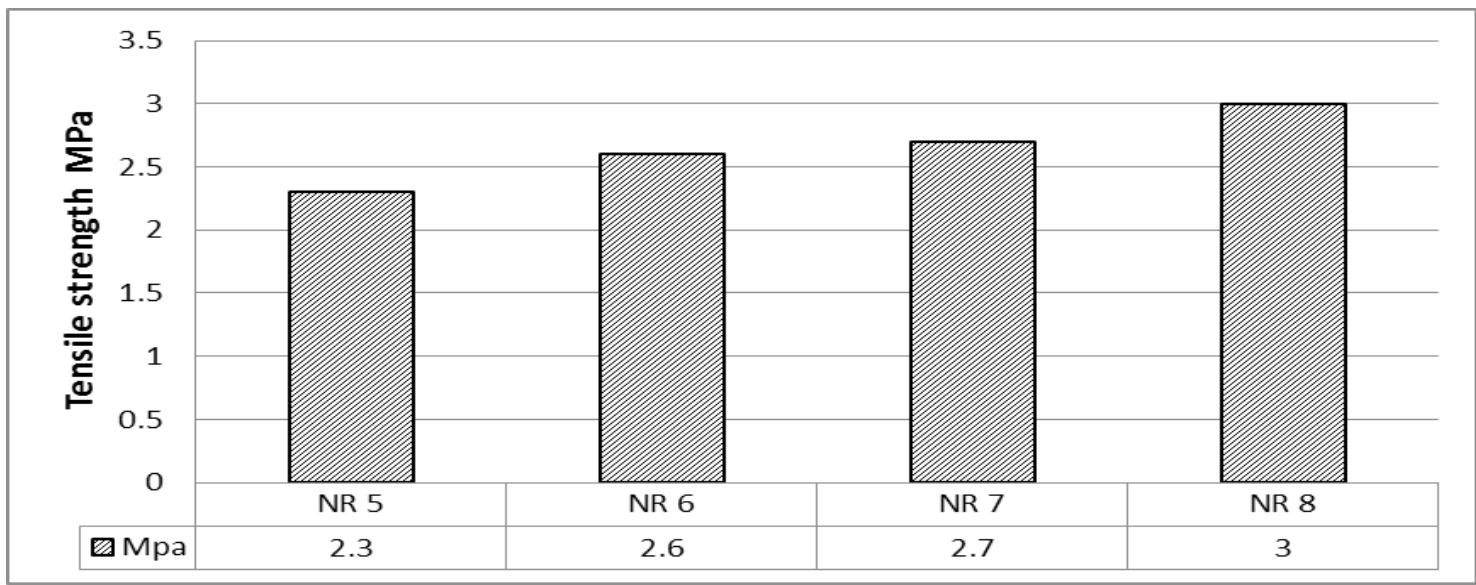

Fig. 10. The effect of addition hybrid filler (mica filler and quartz filler) on tensile strength of NR composites.

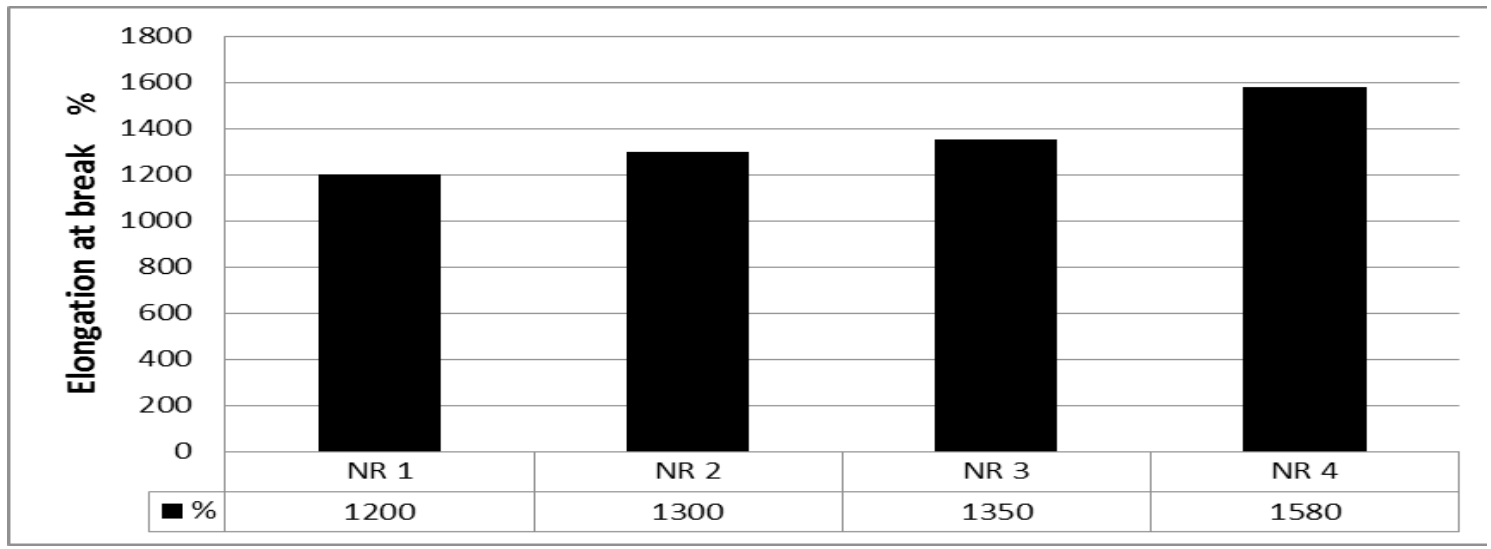

Fig. 11. The effect of addition hybrid filler (mica filler and silica fume filler) on elongation at break of NR composites.

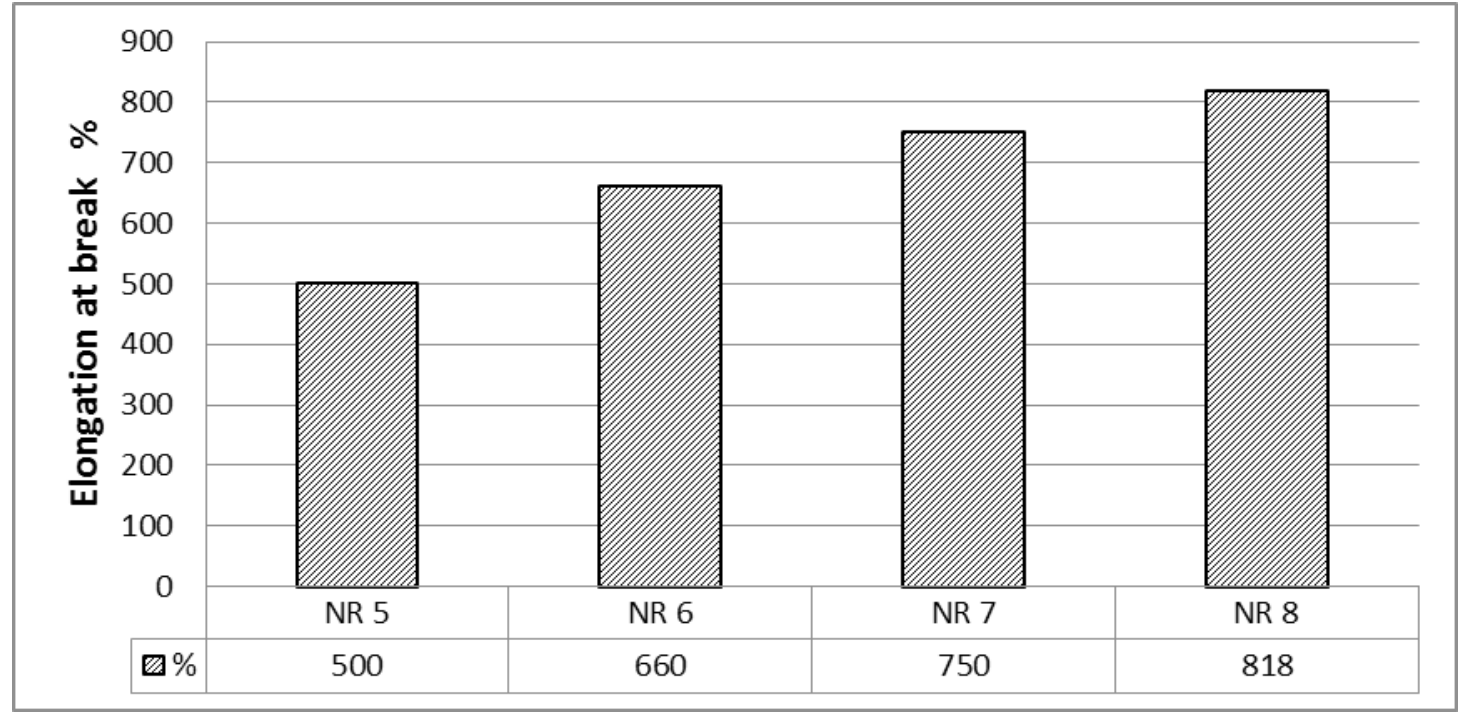

Fig. 12 . The effect of addition hybrid filler (mica filler and quartz filler) on elongation at break of NR composites.

Egypt.J.Chem. 60 , No.5 (2017) 


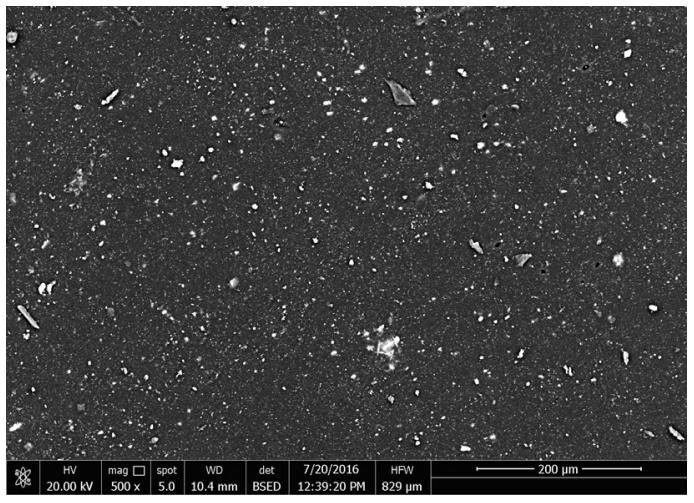

NR

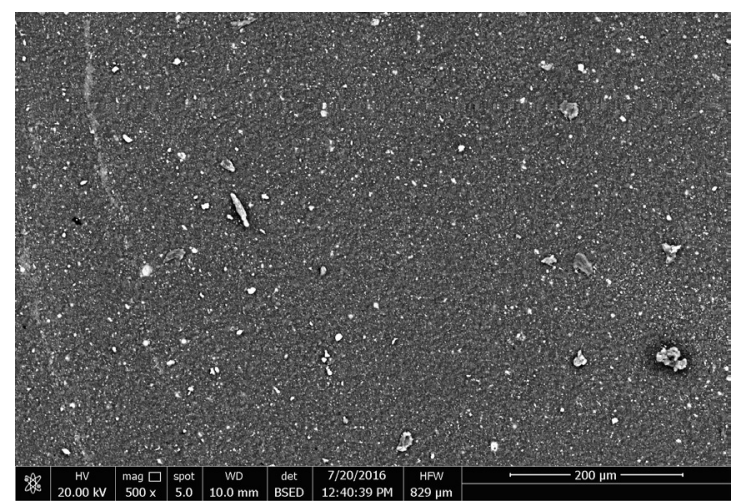

NR/ 20 phr silica fume

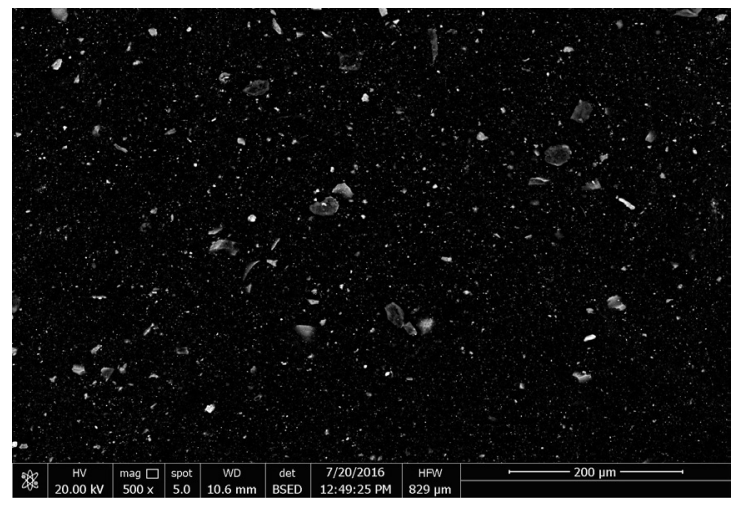

NR/ 20 phr quatrz

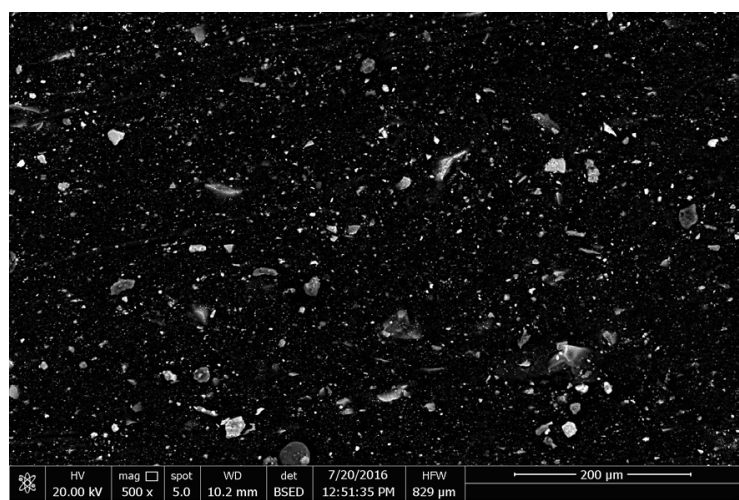

NR/ 50 phr silica fume

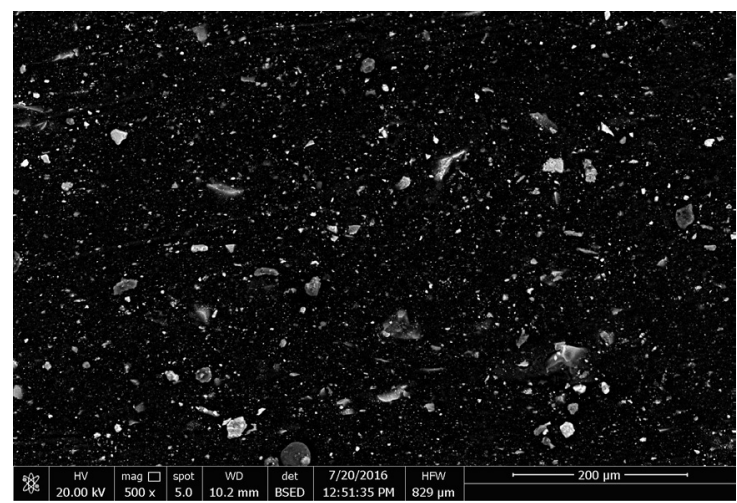

NR/ 50 phr quatrz

Fig. 13. Scanning electron microscopy for NR/silica fume and NR / quartz .

\section{Conclusion}

This paper focused on enhancement the electrical and mechanical properties of Nitrile rubber by using industrial waste (quartz) and silica fume by-product in manufacture of ferrosilicon alloys in Egyptian chemical industries company (KIMA) and the results showed the following:-

1. The addition of different concentrations of industrial waste (quartz) to NR enhanced the dielectric properties of NR, reduce the cost and save the environment from industrial waste. The concentration of quartz( Q10 $=50$ phr) showed the best enhancement in dielectric properties of NR and $(\mathrm{Q} 5=25 \mathrm{phr})$ showed the least enhancement in dielectric properties of NR in all conditions (dry, wet and salinity).

2. The addition of different concentrations of silica fume filler to NR enhanced the Egypt.J.Chem. 60 , No.5 (2017) 
dielectric properties in dry condition and concentration of silica fume $(\mathrm{C} 2=10 \mathrm{phr})$ showed the best enhancement in dielectric properties of NR and (C9 $=45 \mathrm{phr})$ showed the least enhancement in dielectric properties in all conditions (dry, wet and salinity)

3. The addition of quartz filler to NR enhanced the dielectric properties of NR better than silica fume in all conditions (dry, wet and salinity)

4. Nitric acid $30 \%$ lost the dielectric properties for NR blank and also NR filled with silica fume and quartz filler.

5. The addition of different concentrations of mica filler to samples (Q5, C9) which they showed the least enhancement in dielectric properties of NR, the hybrid filler showed enhancement in dielectric properties of NR in two cases (silica fume filler and quartz filler) in all condition dry, wet, salinity and acidity, concentration of mica filler (15 phr) showed the best enhancement in dielectric properties with silica fume filler and quartz filler. by investigation on the effect of addition mica filler on mechanical properties of (Q5, C9) showed enhancement in tensile strength and elongation at break of (Q5, C9) and the concentration of (15 phr) of mica filler added to (Q5, C9) shows the best enhancement in tensile strength and elongation at break of (Q5, C9).

6. The addition of quartz filler to NR enhanced elongation at break of NR but not enhanced tensile strength of NR

7. The addition of silica fume filler to NR enhanced tensile strength and elongation at break and the enhancement degree increase by increasing the concentration of silica fume filler and the concentration of silica fume at $(\mathrm{C} 10=50 \mathrm{phr})$ showed the best enhancement in tensile strength and elongation at break for NR composites.

8. The addition of silica fume filler showed enhancement in mechanical properties (tensile strength and elongation at break) better than quartz filler.

9. Detection on scan electron microscopy at (20 phr and $50 \mathrm{phr}$ ) filler, showed fine distribution was the cause of the performance in both electrical and mechanical properties.

\section{Acknowledgments}

This work was supported by faculty of science at Aswan University, High voltage laboratory in the faculty of Engineering at Aswan University and National Research Centre in Cairo

\section{References}

1. El tony, M.M. and EL-Nemar, K.F. Application of acrylonitrile butadiene rubber for management of industrial waste silica. Material Science and Engineering Journal, 1,1 (2012).

2. Nasir, M. Teh, G.K. The effects of various types of crosslinks on the physical properties of natural rubber. European Polymer Journal, 24(8), 733736(1988).

3. Choi, S.S. Properties of silica-filled styrene butadiene rubber compounds containing acrylonitrile- butadiene rubber: the influence of the acrylonitrile -butadiene. Rubber type Journal Applied Science 85, 385-393(2002).

4. Cai, H. H. Li, S. D. Tian, G. R. Wang, H.B. and Wang, J.H. Reinforcement of natural rubber latex film by ultrafine calcium carbonate. Applied Polymer Journal, 87(6), 982-985(2002).

5. Spiltalsky, Z. Tasis, D. Papagelis, K. and Galiots, C. Carbon nanotube-polymer composites: chemistry, processing, mechanical and electrical properties. process in Polymer Science Journal, 35(31), 357401(2010).

6. Morsy, R.M. Ismaiel, M.N. and Yahia, A.A. Conductivity studies on acrylonitrile butadiene rubber loaded with different types of carbon blacks. International Journal Of Materials, Method And Technology, 1(4), 22-35 (2013).

7. Ismaiel, M. N. and Kalaf, A. I. "Styrenebutadiene rubber/graphite powder composites: rheometricphysicomechanical and morophlolgical properties. Journal Of Applied Polymer Science, 120, 298-304(2011).

8. Kachkurkia, I. Ovcharav, V. Okhtina, O. and Tertyshna, O. Vulcanization peculiarties of rubber of general and special purpose in the presence of zincotaining polymer-inorganic composite. Journal Of Chemistry And Chemical Technology, 3(3), 213220(2009).

9. Frohlich, J. Niedermeier, W. and Luginsland, H.D. The effect of filler-filler and filler-elastomer interaction on rubber reinforcement. composites 
part(A): Applied Science And Manufacturing, 36 (4), 449-460(2005).

10. Hundiwale, D.G. Kapadi, U.R, Desai, M.C. Patil, A.G, and Bidkar, S.H. New economical filler for elastomer composites. Journal Polymer-Plastics Technology And Engineering, 43(3),615-630, (2007).

11. Raffae, A.S.A. ElNashar, D.E. Abd-elmessieh, S.L. and Abd el nour, K.N. Electrical and mechanical properties of acrylonitrile and linear low density polyethylene composites in the vicinity of the percolatin threshold. Journal Materials And Design.30(9), 3760-3769 (2009).

12. Abouzeid, M. M. Radiation effect on properties of black filled NBR/EPDM rubber blends. European Polymer Journal, 43(10), 4415-4422 (2007).

13. Parmanik, P.K. khastgir, D. and Saha, T.N. Conductive nitrile rubber composite containing carbon fillers: studies on mechanical properties and electrical conductivity. Composites, 23(3),183191(1992).

14. Huang, J.C. Carbon black filled conducting polymers and polymer blends. Journal Of Advanced In Polymer Technology, 211(4), 299-313 (2002).

15. Salkhord, S. and Ghari, H.S. Synergistic reinforcement of NBR by hybrid filler system including organocaly and nano-CaCO3. Journal Of Applied Polymer Science, 132(44), 42744(2015).

16. Sobhy, M.S. El-nashr, D.E. and Mazid, N.A. Cure characteristic and physicomechanical properties of calcium carbonate reinforcement rubber composites. Egyptian Journal Of Solids, 26(2), 241257 (2003).

17. EL-nashar, D.E. Rozik, N.N. and Abdel-messieh, S.L. Mechanical and electrical properties of acrylonitrile- butadiene rubber filled with treated nanographite. Journal of Polimery, 59,1122,(2014).

18. Kataizoidou, K. Fukushima, H. and Drazal, L.T. A new compounding method for exfoliated graphite - polyproplenenanocomposite with enhanced flexural properties and lower percolation threshold. Journal Of Composites Science And Technology, 67(10), 2045-2051(2007).

19. Hwang, W.G. Wei , K.H. and Wu, C.M. “ preparation and mechanical properties of nitrile butadiene rubber/ silicates composites. Polymer 45, 5729-5734 (2004).

20. Nah, C. Ryu, H.J. Han, S.H. Rhee, J.M. and Lee, M.H. Fracture behaviour of acrylonitrile butadiene rubber/clay nanocomposite. Journal Of Polymer International, 50,1265-1268 (2001).

21. Yasin, T. Ahmed, S. Yoshii, F. and Makuuchi, K. Effect of acrylonitrile content on physical properties of electron beam irradiated acrylonitrilebutadiene rubber. Journal Of Reactive And Functional Polymers. 57, 113-118 (2003).

22. Burnham, J.T. Givens, P.S. Grisham, T.M. High strength polymer post insulators enable economical transmission lines with low environmental impact. Proceedings of the IEEE Power Engineering Society, 494 -503, April (1994).

23. Nasrat, L. Ali, Z. M. Dardeer, M. M. and Tawfiq, R. Mica filler effect on electrical characteristics of polymers insulators. International Journal of Engineering Innovation \& Research (IJEIE), 5(2), 168-172 (2016).

(Received 6/7 / 2017; accepted 5/9/2017) 


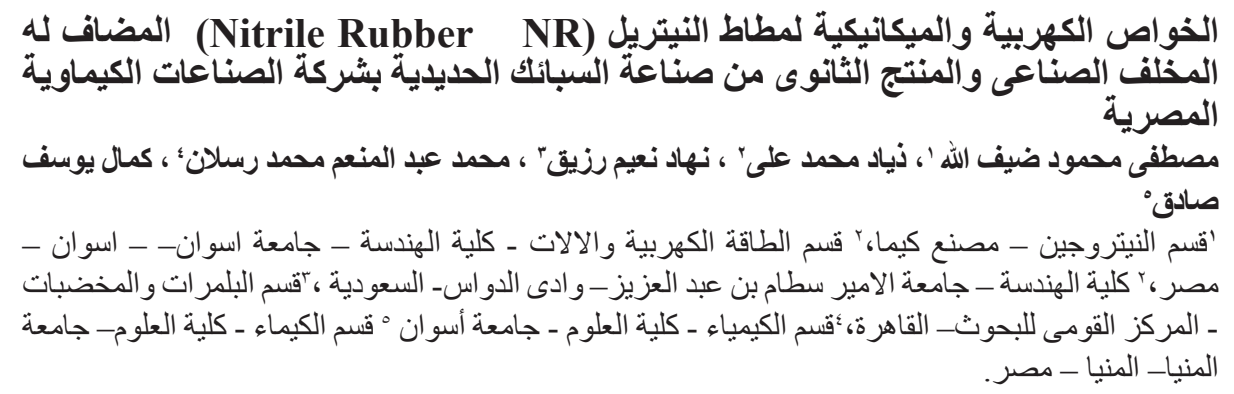

هذا العمل يركز على استخدام غبار السيليكا (المنتج الثنانوى) والكوارتز ( المخلف الصناعى) فى صناعة السبائك الحديدية

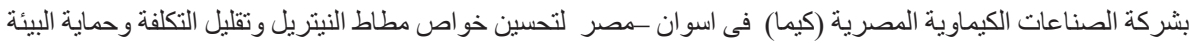
من المخلفات الصناعية . تحضير مثر اكبات مطاط النيتريل عن طريق اضافة تركيز الكيات مختلفة من غبار السيليكا ( المنتج

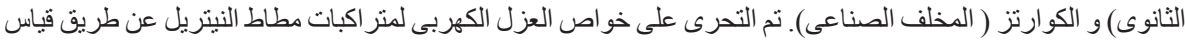

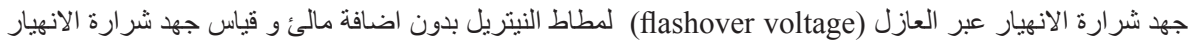

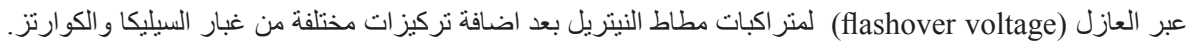

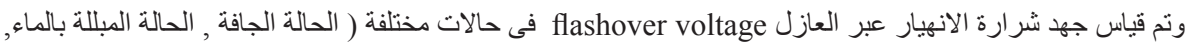

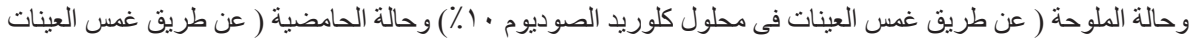

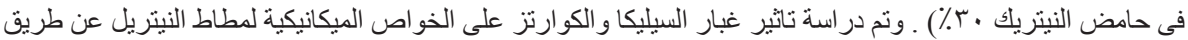

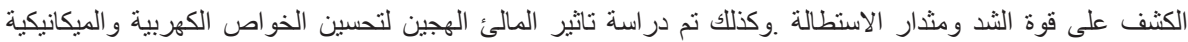

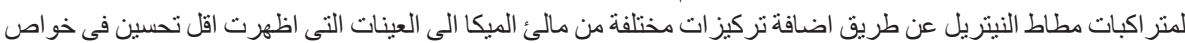

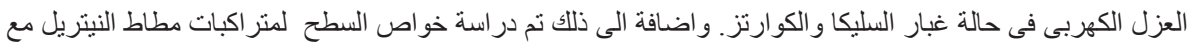
غبار السليكا والكو ارتز. 